\title{
The Effects of Triglyceride Absorption upon Glucagon, Insulin, and Gut Glucagon-Like Immunoreactivity
}

\author{
Ingolf Böttger, Richard Dobbs, Gerald R. Faloona, and \\ ROGER H. UNGER \\ From the Department of Internal Medicine, The University of Texas (South- \\ western) Medical School at Dallas, and Veterans Administration Hospital, \\ Dallas, Texas 75235
}

A B S T R A C T The effects of a fat meal upon plasma insulin, glucagon, and glucagon-like immunoreactivity (GLI) have been studied in conscious dogs and in human volunteers. In dogs the intraduodenal instillation of $10 \mathrm{~g} / \mathrm{kg}$ of peanut oil was accompanied by increases in the mean plasma levels of all three polypeptides that averaged $5 \mu \mathrm{U} / \mathrm{ml}, 107 \mathrm{pg} / \mathrm{ml}$, and $2.1 \mathrm{ng} / \mathrm{ml}$, respectively. $3 \mathrm{~g} / \mathrm{kg}$ of peanut oil, when emulsified with egg yolk, elicited a much greater response of the three hormones, and a physiologic dose of $1 \mathrm{~g} / \mathrm{kg}$ in emulsified form also caused a significant rise in glucagon and GLI. The islet cell hormone response was not ascribable to chylomicronemia since intravenous infusion of canine chyle failed to stimulate glucagon secretion; moreover, in dogs with a thoracic duct fistula in which chyle was excluded from the circulation, the intraduodenal administration of a fat meal elicited the normal islet cell hormone response, as well as a rise in GLI. $10 \mathrm{~g} / \mathrm{kg}$ of mediumchain triglycerides failed to elicit these same responses. In six human volunteers the oral administration of 3 $\mathrm{g} / \mathrm{kg}$ peanut oil was accompanied by increments of 2 $\mu \mathrm{U} / \mathrm{ml}, 26 \mathrm{pg} / \mathrm{ml}$, and $1.5 \mathrm{ng} / \mathrm{ml}$ in the mean levels of insulin, glucagon, and GLI. The changes in insulin and glucagon in man were neither statistically significant nor biologically impressive.

It is concluded that in dogs fat absorption is accompanied by prompt and substantial increases in plasma glucagon and GLI and a small transient rise in insulin. The evidence favors an enterogenic signal to the islets of Langerhans rather than their stimulation by chylomi-

This work was presented at the Southern Society for Clinical Investigation, 27 January 1972, New Orleans, La., and at the American Federation for Clinical Research, 29 April 1972, Atlantic City, N. J.

Dr. Böttger is a Fellow of the Deutsche Forschungsgemeinschaft.

Received for publication 2 June 1972 and in revised form 6 June 1973. crons. Pancreozymin is qualified to serve as such a signal. The physiologic implications of this study are considered.

\section{INTRODUCTION}

The effects of a fat meal upon the hormones of the islets of Langerhans are not well established. Pi-Sunyer et al. (1) described a small rise in insulin after the ingestion of corn oil in man, but others have reported no change in insulin after a fat meal $(2-4)$. The present study was designed to determine the effects of fat ingestion upon the secretion of insulin and glucagon; in addition, the response of glucagon-like immunoreactivity, commonly referred to as GLI or enteroglucagon, a family of polypeptides of uncertain function released from the gastrointestinal tract during glucose absorption, was measured. The results support the existence of a hitherto unsuspected enteroinsular axis for fat that could play a role in triglyceride homeostasis.

\section{METHODS}

Healthy mongrel dogs weighing between 13 and $28 \mathrm{~kg}$ were employed in these studies. 2 days or more before an experiment, a polyethylene catheter was inserted through the jugular vein into the inferior vena cava between the heart and liver, and another was passed through a midline incision into the duodenum for administration of triglycerides. After full recovery of the dog from surgery, the experiment was performed with the animal in a fully conscious state. Blood specimens were obtained at frequent intervals from the inferior vena caval catheter in plastic syringes and transferred into chilled tubes containing 5,000 $\mathrm{U}$ of Trasylol (FBA Pharmaceuticals, New York) and EDTA-Na, $10 \mathrm{mg}$. Specimens were centrifuged immediately at $4^{\circ} \mathrm{C}$. Plasma glucose was determined by the Hoffman method (5) using the Technicon AutoAnalyzer.: Triglycerides were determined by the method of Eggstein and Kreutz (6).

${ }^{1}$ Technicon Corporation, Tarrytown, N. Y. 
Plasma GLI was measured by means of a previously described (7) radioimmunoassay modified as follows: 25 $\mathrm{pg}$ of [205I]glucagon, $250 \mathrm{U}$ of Trasylol, a $50 \mu \mathrm{l}$ plasma sample, and rabbit antiglucagon serum $78 \mathrm{~J}$, which crossreacts strongly with gut GLI in a final dilution of $1: 1,800$, were incubated at $4^{\circ} \mathrm{C}$ for 4 days, the total volume being $0.3 \mathrm{ml}$. Separation of free and bound [ $\left.{ }^{125} \mathrm{I}\right]$ glucagon was performed with dextran-coated charcoal. Pancreatic glucagon was measured by the same technique modified as follows: $15 \mathrm{pg}$ of $\left[{ }^{125} \mathrm{I}\right]$ glucagon, $1,000 \mathrm{U}$ of Trasylol, $200 \mu \mathrm{l}$ of plasma sample and antiserum $30 \mathrm{~K}$, which is highly specific for pancreatic glucagon and which was employed in a final dilution of $1: 60,000$, were incubated in a total volume of $1.2 \mathrm{ml}$. Antiserum G-58, considered even more specific than $30 \mathrm{~K}$, was used in selected experiments. Incubation and separation were performed as described above. Insulin was measured by the radioimmunoassay method of Yalow and Berson (8) as modified by Herbert et al. (9). The latter method measures changes of $2 \mu \mathrm{U} / \mathrm{ml}$ with $95 \%$ confidence.

Normal human volunteers, members of the house staff, were also studied in a similar fashion described in further detail below. Blood samples were obtained through an indwelling butterfly needle. All analytical procedures were identical except that antiserum G-58 was used instead of $30 \mathrm{~K}$ in the glucagon assay. Statistical significance was calculated from $t$ tests based on paired comparisons between the mean base-line values and the experimental period.

\section{RESULTS}

Effect of intraduodenal administration of long-chain triglycerides on insulin, glucagon, and GLI. To determine the effects of a fat meal, $10 \mathrm{~g} / \mathrm{kg}$ of peanut oil was administered intraduodenally over a $15 \mathrm{~min}$ period to a group of nine dogs (Fig. 1). 10 min after the start of intraduodenal instillation of the triglyceride meal, a rise in pancreatic glucagon was observed in every dog. Mean glucagon rose slightly from $96 \mathrm{pg} / \mathrm{ml}(\mathrm{SEM} \pm 21)$ at zero time to $114 \mathrm{pg} / \mathrm{ml}(\mathrm{SEM} \pm 16)$ at $15 \mathrm{~min}$, significantly greater $(P<0.01)$ by paired comparison than the mean of the base line values, and reached peaks of 161 $\mathrm{pg} / \mathrm{ml}(\mathrm{SEM} \pm 28)$ at $60 \mathrm{~min}(P<0.0005)$ and 191 $(\mathrm{SEM} \pm 62)$ at $180 \mathrm{~min}(\mathrm{NS})$. The mean maximal rise of glucagon was $142 \mathrm{pg} / \mathrm{ml}$ (SEM \pm 42$)$. Mean insulin rose from $12 \mu \mathrm{U} / \mathrm{ml}(\mathrm{SEM} \pm 3)$ at zero time to $17 \mu \mathrm{U} /$ $\mathrm{ml}(\mathrm{SEM} \pm 7)$ at $15 \mathrm{~min}$, not significantly greater than the mean of the base-line values, and returned to baseline levels within $20 \mathrm{~min}$ after the triglyceride meal. The mean maximal rise in insulin was $10.4 \mu \mathrm{U} / \mathrm{ml}$ (SEM \pm 4.2).

GLI increased from a fasting value of $1.4 \mathrm{ng} / \mathrm{ml}$ to a peak of $3.5 \mathrm{ng} / \mathrm{ml}$ at $150 \mathrm{~min}$; statistically significant increases above the mean of the base-line values were observed from 30 to $240 \mathrm{~min}(P<0.02)$. Triglycerides rose to a peak of $91 \mathrm{mg} / 100 \mathrm{ml}(\mathrm{SEM} \pm 11)$ at $180 \mathrm{~min}$; most of the increase occurred during the $2 \mathrm{nd} h$ of the experiments.

The increases in mean glucagon and GLI observed in Fig. 1 occurred simultaneously, thus raising the question of a relationship between the two events. While an

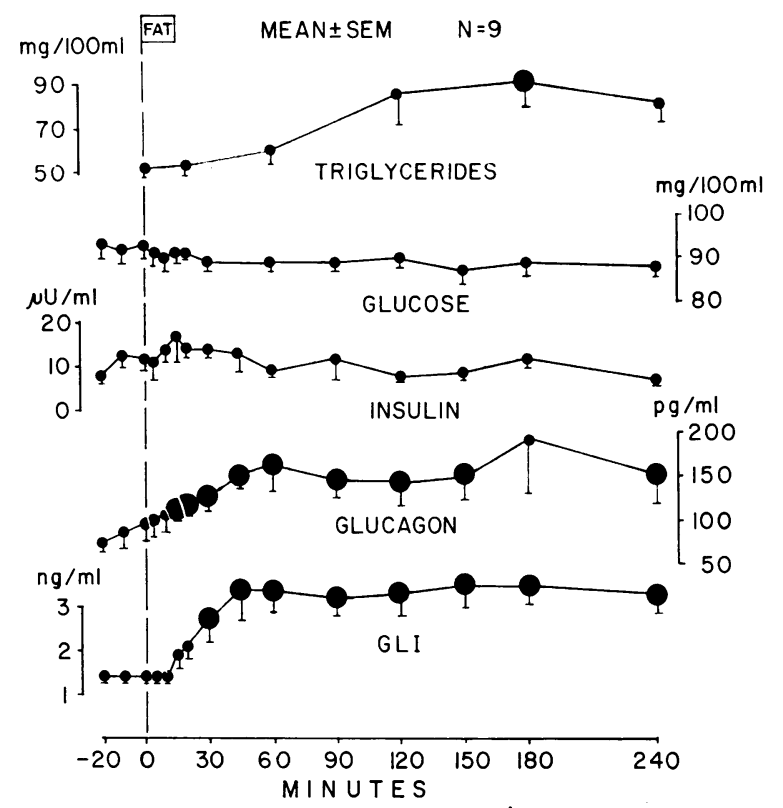

Figcre 1 The effect of intraduodenal administration of 10 $\mathrm{g} / \mathrm{kg}$ of peanut oil on glucagon, insulin, and GLI in a group of nine conscious dogs. Large circles signify points which differ statistically $(P<0.02)$ from the mean of the three base-line values.

increase in immunoreactivity measured in this glucagon assay probably reflects a true increase in the pancreatic hormone, cross-reaction between high levels of "enteroglucagon" or GLI and the antibodies employed in the assay for pancreatoglucagon, which, despite their high specificity, do cross-react very weakly with gut GLI, is a theoretical possibility. In order to exclude it, three dogs with indwelling catheters in both the pancreaticoduodenal vein and in the inferior vena cava were given an intraduodenal fat load of $10 \mathrm{~g} / \mathrm{kg}$, and pancreatic glucagon was measured in plasma obtained from both sides. As shown in Fig. 2 the concentration of immunoreactivity measured in the pancreatic glucagon assay was consistently higher in the pancreaticoduodenal vein than in the inferior vena cava throughout the period of the rise in vena caval GLI, indicating that it originates in the tissues drained by the pancreaticoduodenal vein. Thus, despite its general parallelism with GLI, the immunoreactivity measured in the assay for pancreatic glucagon is probably derived from the pancreas rather than the gut.

The effect of intraduodenal administration of emulsified long-chain triglycerides. The rapid instillation into the duodenum of a large volume of unemulsified oil is an unphysiologic maneuver which was employed in these studies to eliminate certain variables that would be present under more physiologic circumstances. To determine the effect of smaller amounts of emulsified fat, $3 \mathrm{~g} / \mathrm{kg}$ of 


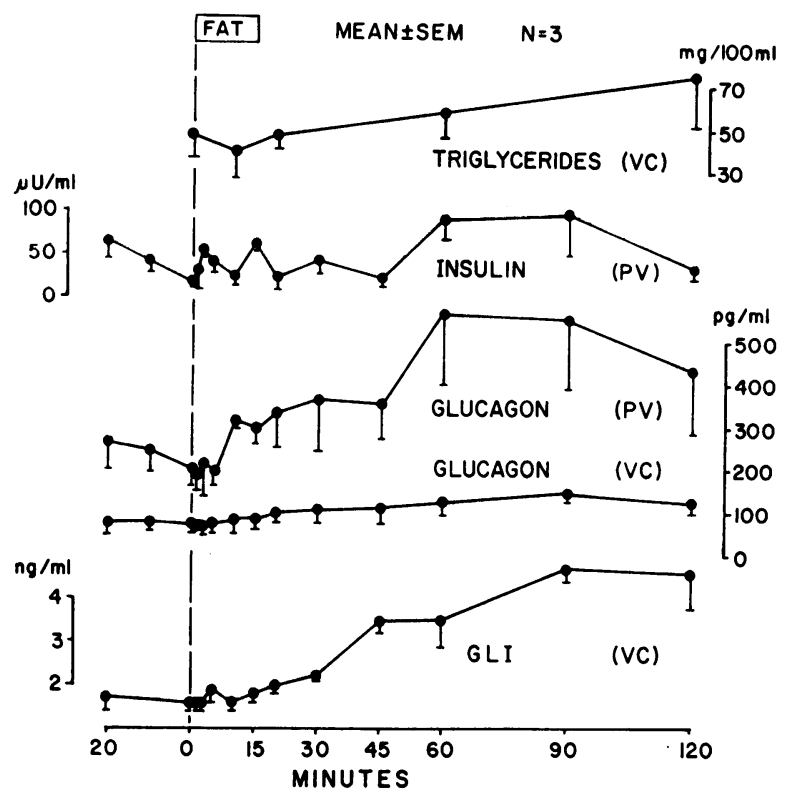

Figure 2 Pancreatoglucagon levels measured simultaneously in the pancreatic vein (PV) and vena cava (VC) after the intraduodenal administration of $10 \mathrm{~g} / \mathrm{kg}$ of peanut oil to a group of three conscious dogs.

fat was mixed with $2 / 3$ of an egg yolk and administered intraduodenally to three dogs. The results are shown in Fig. 3. All three hormones rose as observed previously, but the rises were more rapid and substantial in these experiments, possibly because of increased fat absorption reflected by a greater rise in serum triglycerides to more than $100 \mathrm{mg} / 100 \mathrm{ml}$ at $180 \mathrm{~min}$. Mean insulin rose promptly from $9 \mu \mathrm{U} / \mathrm{ml}(\mathrm{SEM} \pm 1)$ at zero time to 22 $\mu \mathrm{U} / \mathrm{ml}(\mathrm{SEM} \pm 8)$ at $20 \mathrm{~min}(\mathrm{NS})$. Glucagon rose from $49 \mathrm{pg} / \mathrm{ml}(\mathrm{SEM} \pm 11)$ to a peak of $303 \mathrm{pg} / \mathrm{ml}(\mathrm{SEM} \pm$ 26) at $60 \mathrm{~min}$ and declined rapidly thereafter. GLI rose from $1.8 \mathrm{ng} / \mathrm{ml}(\mathrm{SEM} \pm 0.2)$ to a peak of $15.0 \mathrm{ng} / \mathrm{ml}$ $(\mathrm{SEM} \pm 0.6)$ at $60 \mathrm{~min}(P<0.005)$ and declined thereafter, again following a course parallel to that of glucagon. Increments were statistically significant at 45,60 , and $240 \min (P<0.02)$.

To determine the effect of quantities of fat within the physiologic range of a normal meal, $1 \mathrm{~g} / \mathrm{kg}$ of peanut oil emulsified with $\frac{1}{3}$ of an egg was administered to a group of four dogs. The results, recorded in Table I, revealed in all dogs hormonal changes qualitatively similar to those observed with larger doses. Mean glucagon rose from $51 \mathrm{pg} / \mathrm{ml}(\mathrm{SEM} \pm 16)$ to a peak of $120 \mathrm{pg} / \mathrm{ml}$ $(\mathrm{SEM} \pm 9)$ at $60 \mathrm{~min},(P<0.01)$ and returned to baseline levels at $180 \mathrm{~min}$. Insulin rose slightly at $5 \mathrm{~min}$ from $7 \mu \mathrm{U} / \mathrm{ml}(\mathrm{SEM} \pm 0.4)$ to $11 \mu \mathrm{U} / \mathrm{ml}(\mathrm{SEM} \pm 2.0)$, again not statistically significant, and remained between those levels thereafter. GLI rose from $0.9 \mathrm{ng} / \mathrm{ml}(\mathrm{SEM} \pm 0.1)$ to a peak of $4.4(\mathrm{SEM} \pm 1.2)$ at $60 \mathrm{~min}(P<0.01)$. Tri- glycerides rose from $37 \mathrm{mg} / 100 \mathrm{ml}(\mathrm{SEM} \pm 3$ ) to a maximum of $76 \mathrm{mg} / 100 \mathrm{ml}(\mathrm{SEM} \pm 6)$ at 150 and $180 \mathrm{~min}$. The changes in glucagon and GLI were only slightly less than those observed with $10 \mathrm{~g} / \mathrm{kg}$ of unemulsified fat.

In the experiments with $3 \mathrm{~g} / \mathrm{kg}$ of fat, the dogs received in addition to the triglycerides $2 / 3$ of an egg yolk, which contains approximately $2 \mathrm{~g}$ of protein, itself a stimulus to glucagon secretion (10), and in the $1 \mathrm{~g} / \mathrm{kg}$ experiments $\frac{1}{3}$ of a yolk was administered. To determine the magnitude of any possible contribution of the egg yolk to the hormonal responses observed, two egg yolks, 3-6 times the quantity employed to emulsify the fat, were administered intraduodenally in a group of three dogs. The results are shown in Table II. Although there was a small rise in all three hormones, it is clear that the protein in the egg yolk could not, by itself, account for the responses observed in the experiments employing emulsified fat.

The parallelism of the glucagon and GLI responses in Fig. 3 again raises the question of whether cross-reactivity between GLI and antiserum $30 \mathrm{~K}$ could account for the apparent rise in pancreatic glucagon. To determine the source of the immunoreactivity measured in the $30 \mathrm{~K}$ assay in these experiments, pancreaticoduodenal vein and inferior vena caval plasma were obtained simultaneously after the intraduodenal administration of $3 \mathrm{~g} / \mathrm{kg}$ of fat emulsified with egg yolk. Pancreatic glucagon was mea-

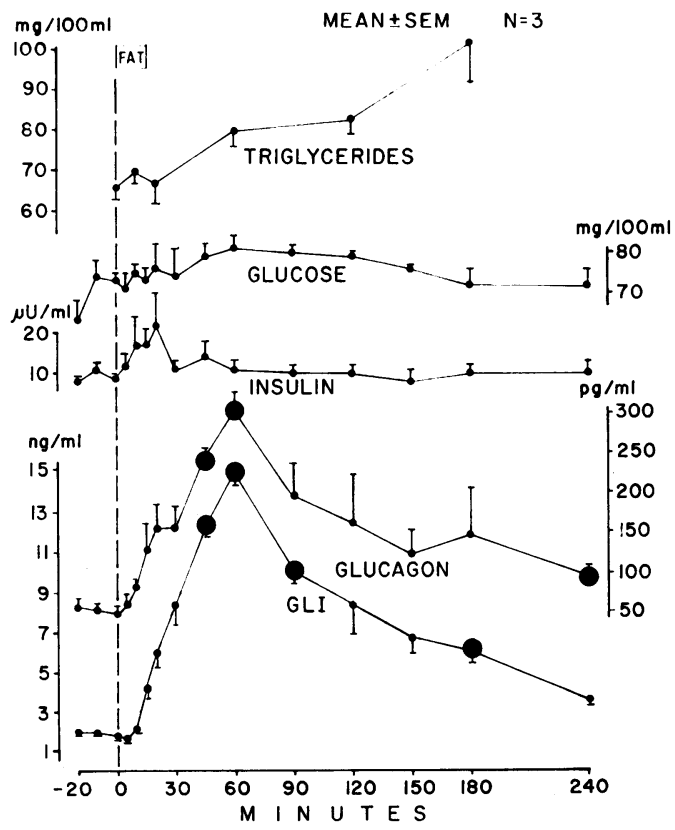

FIGURE 3 The effect of $3 \mathrm{~g} / \mathrm{kg}$ of intraduodenally administered peanut oil emulsified with egg yolk upon glucagon, insulin, and GLI in a group of three conscious dogs. The large circles signify points which differ statistically $(P$ $<0.02$ ) from the mean of the three base-line values. 
TABLE I

Effects of Intraduodenal Administration of $1 \mathrm{~g} / \mathrm{kg}$ of Peanut Oil, Emulsified with Egg Yolk, on Plasma Glucagon, Insulin, and GLI in Four Dogs

\begin{tabular}{|c|c|c|c|c|c|c|c|c|c|c|c|c|c|c|c|c|}
\hline & Min ....... & -20 & -10 & 0 & 5 & 10 & 15 & 20 & 30 & 45 & 60 & 90 & 120 & 150 & 180 & 240 \\
\hline $\begin{array}{l}\text { Triglycerides } \\
\quad \pm \mathrm{SEM}\end{array}$ & Mean $(m g / 100 m l)$ & & & $\begin{array}{r}37 \\
3\end{array}$ & & $\begin{array}{r}38 \\
2\end{array}$ & & $\begin{array}{r}39 \\
3\end{array}$ & & & $\begin{array}{r}54 \\
2\end{array}$ & & $\begin{array}{r}73 \\
3\end{array}$ & $\begin{array}{r}76 \\
6\end{array}$ & $\begin{array}{r}76 \\
8\end{array}$ & $\begin{array}{l}70 \\
10\end{array}$ \\
\hline $\begin{array}{l}\text { Insulin } \\
\quad \pm \text { SEM }\end{array}$ & Mean $(\mu U / m l)$ & $\begin{array}{l}8 \\
0.6\end{array}$ & $\begin{array}{l}7 \\
0.7\end{array}$ & $\begin{array}{l}7 \\
0.4\end{array}$ & $\begin{array}{l}11 \\
2.0\end{array}$ & $\begin{array}{l}8 \\
0.3\end{array}$ & $\begin{array}{l}8 \\
0.5\end{array}$ & $\begin{array}{l}10 \\
0.8\end{array}$ & $\begin{array}{l}9 \\
1.5\end{array}$ & $\begin{array}{c}10 \\
1.8\end{array}$ & $\begin{array}{l}10 \\
1.7\end{array}$ & $\begin{array}{l}8 \\
1.8\end{array}$ & $\begin{array}{l}8 \\
0.8\end{array}$ & $\begin{array}{l}7 \\
0.4\end{array}$ & $\begin{array}{l}8 \\
0.7\end{array}$ & $\begin{array}{l}8 \\
0.8\end{array}$ \\
\hline $\begin{array}{l}\text { Glucagon } \\
\quad \pm \mathrm{SEM}\end{array}$ & Mean $(p g / m l)$ & $\begin{array}{l}54 \\
13\end{array}$ & $\begin{array}{l}50 \\
12\end{array}$ & $\begin{array}{l}51 \\
16\end{array}$ & $\begin{array}{l}60 \\
15\end{array}$ & $\begin{array}{l}50 \\
13\end{array}$ & $\begin{array}{l}57 \\
15\end{array}$ & $\begin{array}{c}76 \\
5\end{array}$ & $\begin{array}{c}82 * \\
6\end{array}$ & $\begin{array}{c}113 \ddagger \\
9\end{array}$ & $\begin{array}{c}120^{*} \\
9\end{array}$ & $\begin{array}{c}98 \\
11\end{array}$ & $\begin{array}{r}78 \\
6\end{array}$ & $\begin{array}{r}68 \\
5\end{array}$ & $\begin{array}{r}59 \\
8\end{array}$ & $\begin{array}{l}55 \\
14\end{array}$ \\
\hline $\begin{array}{l}\text { GLI } \\
\quad \pm \text { SEM }\end{array}$ & Mean $(n g / m l)$ & $\begin{array}{l}1.0 \\
0.1\end{array}$ & $\begin{array}{l}1.0 \\
0.1\end{array}$ & $\begin{array}{l}0.9 \\
0.1\end{array}$ & $\begin{array}{l}1.0 \\
0.1\end{array}$ & $\begin{array}{l}0.9 \\
0.1\end{array}$ & $\begin{array}{l}1.1 \\
0.1\end{array}$ & $\begin{array}{l}1.5 \\
0.3\end{array}$ & $\begin{array}{l}2.3 \\
0.6\end{array}$ & $\begin{array}{l}3.8^{*} \\
0.7\end{array}$ & $\begin{array}{l}4.4 \\
1.2\end{array}$ & $\begin{array}{l}3.6 \\
1.2\end{array}$ & $\begin{array}{l}2.2 \\
0.6\end{array}$ & $\begin{array}{l}1.9 \\
0.7\end{array}$ & $\begin{array}{l}1.7 \\
0.3\end{array}$ & $\begin{array}{l}1.4 \\
0.2\end{array}$ \\
\hline
\end{tabular}

$* P<0.05$.

$\ddagger P<0.01$.

sured both with $30 \mathrm{~K}$ and with the antiserum G-58, which is even more specific for pancreatic glucagon. ${ }^{2}$ As shown in Fig. 4 and in Table III, immunoreactivity measured with both $30 \mathrm{~K}$ and G-58 was consistently higher in the pancreaticoduodenal vein than in the vena cava, evidence of its pancreaticoduodenal origin. By contrast, total GLI measured in the much less sensitive $78 \mathrm{~J}$ assay was discernibly greater in this vein early after the administration of the fat but during the peak GLI rise was below the vena caval levels. The fact that pancreaticoduodenal vein immunoreactivity measured with both the G-58 and $30 \mathrm{~K}$ assays remained more than twice as high as in the vena cava when total pancreaticoduodenal vein level of GLI measured with the 78J assay fell below vena caval GLI, which rose ninefold, suggests that the gradients

${ }^{2}$ Using G-58 antiserum, zero readings for plasma glucagon were obtained in the portal vein of depancreatized dogs during stimulation of GLI release by an intraduodenal glutose load to levels 5,600 and $7,000 \mathrm{pg} / \mathrm{ml}$. obtained with the former antisera represent pancreatic glucagon rather than duodenal GLI.

The duodenum contains only very small quantities of GLI compared with the rest of the upper gut, but a massive GLI release could conceivably account for the higher levels of G-58 and $30 \mathrm{~K}$ immunoreactivity in pancreaticoduodenal vein plasma. To examine this possibility pancreatoduodenal vein vena caval gradients obtained at each point in each experiment are compared in Table IV. On the basis of assays of all fractions of duodenal GLI shown in Table IV, if cross-reacting duodenal GLI, rather than pancreatic glucagon, were responsible for the persistent pancreatic vein-vena caval immunoreactivity gradient observed with G-58 and $30 \mathrm{~K}$, a persistent gradient in the 78J assay measuring at least 10 times that obtained with $30 \mathrm{~K}$ would be present throughout. However, gradients 10 times greater than $30 \mathrm{~K}$ gradients were not observed in these studies, excluding the possibility that the $30 \mathrm{~K}$ and G-58 gradients are of duodenal origin.

TABLE II

Effects of Intraduodenal Administration of Two Egg Yolks upon Plasma Insulin, Glucagon, and GLI in Three Dogs

\begin{tabular}{|c|c|c|c|c|c|c|c|c|c|c|c|c|c|c|c|}
\hline & \multirow[b]{2}{*}{-20} & \multirow[b]{2}{*}{-10} & \multirow[b]{2}{*}{0} & \multicolumn{3}{|c|}{ Egg yolk } & \multirow[b]{2}{*}{20} & \multirow[b]{2}{*}{30} & \multirow[b]{2}{*}{45} & \multirow[b]{2}{*}{ 6) } & \multirow[b]{2}{*}{90} & \multirow[b]{2}{*}{120} & \multirow[b]{2}{*}{150} & \multirow[b]{2}{*}{180} & \multirow[b]{2}{*}{240} \\
\hline $\operatorname{Min}$. & & & & 5 & 10 & 15 & & & & & & & & & \\
\hline Glucose mean $(\mathrm{mg} \quad 100 \mathrm{ml})$ & 91 & 88 & 89 & & 86 & 87 & 86 & 89 & & 91 & 92 & 86 & 84 & 84 & 86 \\
\hline$\pm \mathrm{SEM}$ & 2 & 4 & 2 & & 4 & 4 & 2 & 3 & & 2 & 3 & 2 & 1 & 3 & 2 \\
\hline \multirow{2}{*}{$\begin{array}{l}\text { Insulin mean }(\mu l / m l) \\
\quad \pm \text { SEM }\end{array}$} & 12 & 6 & 14 & 12 & 14 & 9 & 12 & 13 & 9 & 8 & 8 & 8 & 9 & $\tau$ & 6 \\
\hline & 4 & 1 & 7 & 4 & 2 & 1 & 2 & 1 & 1 & 1 & 2 & 1 & 4 & 2 & 0) \\
\hline \multirow{2}{*}{$\begin{array}{l}\text { Glucagon mean }(p g / m l) \\
\quad \pm \text { SFM }\end{array}$} & 55 & 54 & 52 & 93 & 91 & 94 & 95 & 100 & 112 & 90 & 68 & 67 & 6.3 & 67 & 74 \\
\hline & 28 & 29 & 27 & 58 & 52 & 46 & 35 & 39) & 3.3 & 40 & 2.3 & 38 & .38 & 44 & 50 \\
\hline \multirow{2}{*}{$\begin{array}{l}\text { (iLI mean }(n g m l) \\
\quad \pm \mathrm{SEM}\end{array}$} & & 0.9 & 1.0 & 1.1 & 1.3 & 1.4 & 1.4 & $1 . \bar{i}$ & 2.0 & 2.0 & 1.9 & $1 . .3$ & 1.1 & 1.1 & 1. \\
\hline & & 0.2 & 0.1 & 0.3 & 0.2 & 0.2 & 0.2 & 0.2 & 0.3 & 0.4 & 0.3 & 0.1 & 0.3 & 0.2 & 0. \\
\hline \multirow{2}{*}{$\begin{array}{l}\text { Triglycerides mean }(\mathrm{mg} / 100 \mathrm{ml}) \\
\quad \pm \mathrm{SEM}\end{array}$} & & & 48 & & 48 & & 49 & & & 61 & & 91 & & 76 & 57 \\
\hline & & & 6 & & 6 & & 8 & & & 13 & & 24 & & 20 & 4 \\
\hline
\end{tabular}




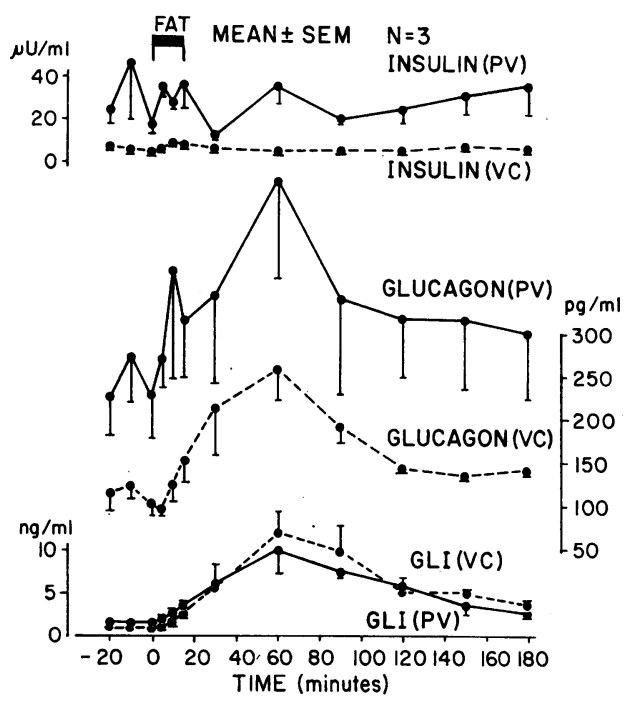

FIGURE 4 The effect of intraduodenal administration of 3 $\mathrm{g} / \mathrm{kg}$ of peanut oil emulsified in egg yolk upon pancreaticoduodenal vein (PV) and inferior vena caval (VC) glucagon, GLI, and insulin in a group of three conscious dogs.

Moreover, there is no correlation between the pancreaticoduodenal vein-inferior vena caval immunoreactivity gradients obtained with G-58 and 78J $(r=0.05)$. Clearly, all or most of the increase in $30 \mathrm{~K}$ and G-58 immunoreactivity must be of pancreatic origin, despite its parallelism with $78 \mathrm{~J}$ immunoreactivity.

The effect of triglycerides in human subjects. To determine if similar responses to fat occur in man, six healthy young men were given $3 \mathrm{~g} / \mathrm{kg}$ of peanut oil with two egg yolks. The results are shown in Fig. 5. Triglycerides rose from $96 \mathrm{mg} / 100 \mathrm{ml}(\mathrm{SEM} \pm 13)$ to 129 $\mathrm{mg} / 100 \mathrm{ml}(\mathrm{SEM} \pm 23)$ at $180 \mathrm{~min}$ and were not measured thereafter. Mean insulin rose only $2 \mu \mathrm{U} / \mathrm{ml}$ $(\mathrm{SEM} \pm 1)$ at $30 \mathrm{~min}(\mathrm{NS})$, and the mean maximal rise in insulin was only $4 \mu \mathrm{U} / \mathrm{ml}(\mathrm{SEM} \pm 1)$, changes of questionable biological importance. Glucagon rose from $81 \mathrm{pg} / \mathrm{ml}(\mathrm{SEM} \pm 14)$ at zero time to $107 \mathrm{pg} / \mathrm{ml}$ $(\mathrm{SEM} \pm 18)(\mathrm{NS})$, and the mean maximal rise was 36 $\mathrm{pg} / \mathrm{ml}(\mathrm{SEM} \pm 7)$. GLI rose from $0.7 \mathrm{ng} / \mathrm{ml}$ (SEM \pm $0.2)$ to a peak of $2.2 \mathrm{ng} / \mathrm{ml}(\mathrm{SEM} \pm 0.4)$ at $360 \mathrm{~min}$ $(P<0.02)$, and the increments were statistically significant $(P<0.02)$ at 60,240 , and $300 \mathrm{~min}$ as well).

These subjects received between 4.5 and $6 \mathrm{~g}$ of egg yolk protein in their fat meal. For control purposes the effect of a comparable quantity of protein upon insulin, glucagon, and GLI was studied in four of this group of volunteers. $6 \mathrm{~g}$ of egg white protein was administered. The results, shown in Table V, reveal no statistically significant changes in any of these parameters. Mean insulin rose slightly at $15 \mathrm{~min}$, and glucagon rose slightly at 45 and $120 \mathrm{~min}$ to approximately the same levels observed in the fat experiments. The mean maximal rise was $22 \mathrm{pg} / \mathrm{ml}(\mathrm{SEM} \pm 8)$, not significantly different from the mean maximal rise of $36 \mathrm{pg} / \mathrm{ml}$ (SEM \pm $\tau$ ) in glucagon observed with egg yolk. GLI did not change.

The effect of intravenously induced chylomicronemia upon glucagon, insulin, and GLI. The increase in pancreatic glucagon secretion observed in dogs during the absorption of fat could be the consequence of either

TABLE III

Effect of Intraduodenal Administration of Peanut Oil upon Mean Glucose, Insulin Glucagon (Assayed with $30 K$ and G58), and GLI

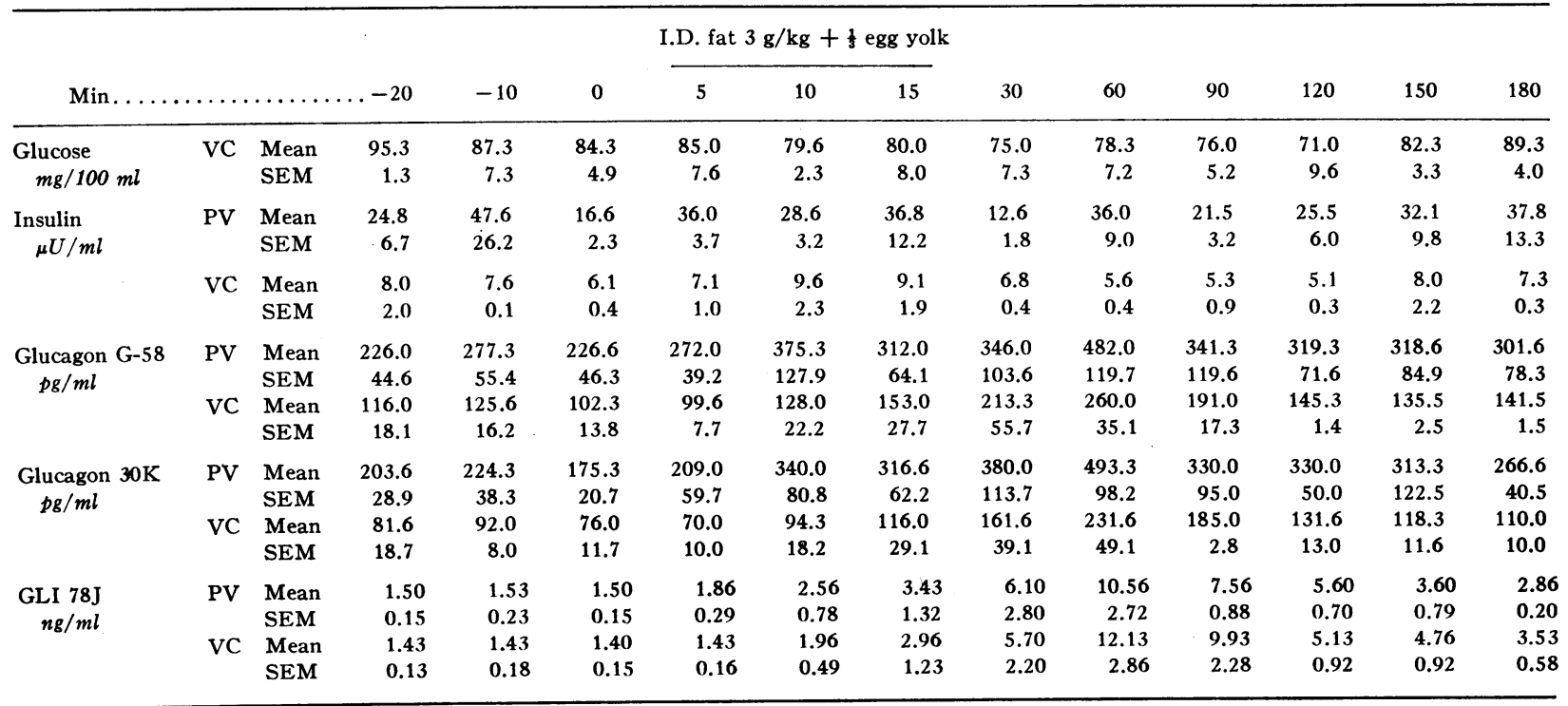


TABLE IV

Pancreaticoduodenal Vein-Vena Caval Differences in Glucagon and GLI during Absorption of Fat $\left(3 \mathrm{~g} / \mathrm{kg}\right.$ and $\frac{1}{3}$ egg yolk $)$

\begin{tabular}{|c|c|c|c|c|c|c|c|c|c|c|c|c|c|}
\hline${ }_{\text {Dog }}{ }^{\mathrm{Mi}}$ & Assay & -20 & -10 & 0 & 5 & 10 & 15 & 30 & 60 & 90 & 120 & 150 & 180 \\
\hline \multirow[t]{3}{*}{ I } & $30 \mathrm{~K}$ & 180 & 200 & 202 & 240 & 375 & 290 & 270 & 135 & 55 & 250 & 135 & 160 \\
\hline & G-58 & 160 & 205 & 180 & 237 & 462 & 240 & 255 & 156 & 68 & 225 & 172 & 237 \\
\hline & $78-\mathrm{J}$ & 100 & 0 & 100 & 400 & 400 & 800 & 0 & 0 & 0 & 0 & 0 & 0 \\
\hline \multirow[t]{3}{*}{ II } & $30 \mathrm{~K}$ & 50 & 100 & 62 & 35 & 184 & 130 & 315 & 270 & 50 & 120 & 40 & 100 \\
\hline & G-58 & 48 & 73 & 60 & 140 & 145 & 101 & 100 & 10 & 28 & 35 & - & - \\
\hline & $78-\mathrm{J}$ & 100 & 100 & 100 & 700 & 2200 & 500 & 3200 & 0 & 900 & 1400 & 0 & 300 \\
\hline \multirow[t]{3}{*}{ III } & $30 \mathrm{~K}$ & 230 & 128 & 192 & 365 & 890 & 440 & 1150 & 1070 & $>2000$ & 1285 & 1420 & 1210 \\
\hline & G-58 & 234 & 176 & 215 & 402 & 965 & 440 & 1060 & 990 & 1660 & 1150 & - & 1000 \\
\hline & $78-\mathrm{J}$ & 400 & 200 & 300 & 400 & 1300 & 0 & 1700 & 2200 & 500 & 2600 & - & 2300 \\
\hline \multirow[t]{3}{*}{ IV } & $30 \mathrm{~K}$ & 137 & 97 & 134 & 142 & 178 & 182 & 70 & 480 & 330 & 225 & 410 & 210 \\
\hline & G-58 & 122 & 177 & 143 & 120 & 135 & 136 & 43 & 500 & 355 & 262 & 337 & 240 \\
\hline & $78-J$ & 0 & 200 & 0 & 200 & 200 & 100 & 0 & 0 & 0 & 700 & 0 & 0 \\
\hline
\end{tabular}

alpha cell stimulation by chylomicronemia, a stimulating signal from the gastrointestinal tract released during fat absorption, or a combination of both. To distinguish between these three possibilities, chylomicronemia was induced by intravenous means so as to bypass intestinal absorption.

Thoracic duct chyle, collected from anesthetized dogs after the intraduodenal administration of peanut oil, was infused intravenously within $20 \mathrm{~h}$ of its collection at a rate of $1.1-2.1 / \mathrm{min}$ for $60 \mathrm{~min}$ in a group of five conscious dogs (Fig. 6). Although the mean triglyceride concentration rose above the highest values observed after intraduodenal administration of peanut oil, pancreatic glucagon and GLI did not change significantly. Insulin rose only slightly from $10 \mu \mathrm{U} / \mathrm{ml}(\mathrm{SEM} \pm 3)$ at zero time to $13 \mu \mathrm{U} / \mathrm{ml}(\mathrm{SEM} \pm 2)$ at $30 \mathrm{~min}(P<$ $0.025), 12 \mu \mathrm{U} / \mathrm{ml}(\mathrm{SEM} \pm 3)$ at $40 \mathrm{~min}(P<0.02)$, and $13 \mu \mathrm{U} / \mathrm{ml}(\mathrm{SEM} \pm 2)$ at $60 \mathrm{~min}(P<0.01)$. These extremely small changes were statistically significant when compared with the mean base-line level.

These results suggest that the rise in glucagon observed after a fat meal is not the consequence of chylomicronemia itself but is the result of a signal from the intestinal tract to the islets of Langerhans released during triglyceride absorption.

Effect of intestinal fat absorption without chylomicronemia upon glucagon, insulin, and GLI. If, in fact, a gut signal discharged during triglyceride absorption is alone responsible for the rise in glucagon and, at least in part, for the variable rise in insulin observed after a fat meal, a comparable bihormonal response would be expected even if the absorbed fat were excluded from the circulation by means of a thoracic duct fistula. In order to determine if this, in fact, does occur, a group of five dogs with a previously established thoracic duct fistula were given $10 \mathrm{~g} / \mathrm{kg}$ of peanut oil via an intraduodenal catheter.

As shown in Fig. 7, mean triglycerides did not change at any time in the 240 -min experiments, indicating that most or all of the absorbed fat had been excluded from

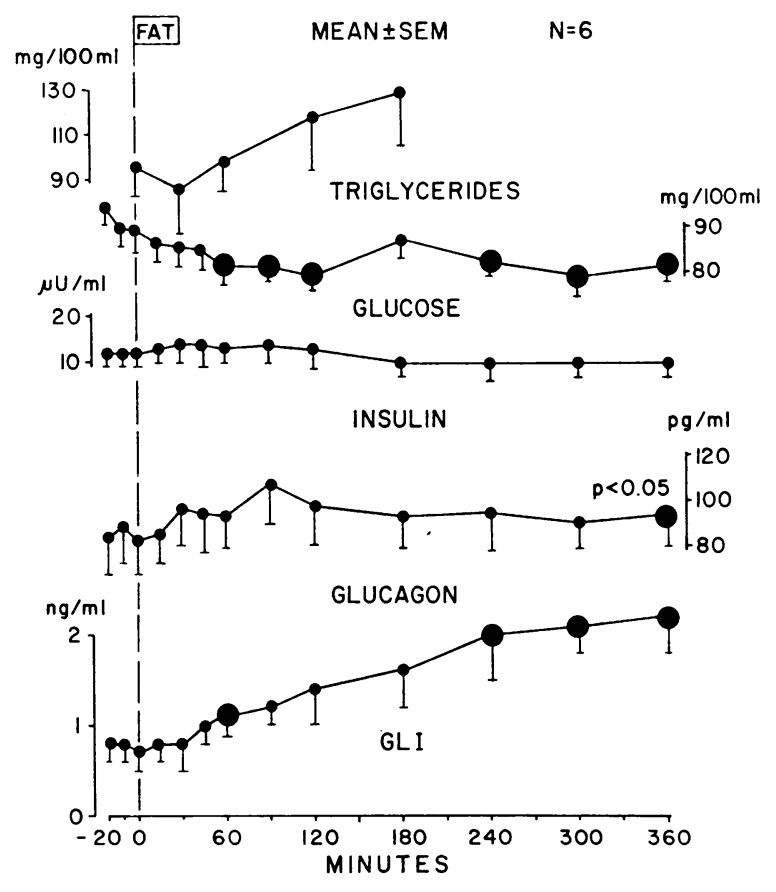

FIgURE 5 The effect of $3 \mathrm{~g} / \mathrm{kg}$ of orally administered peanut oil with egg yolk upon glucagon, insulin, and GLI in a group of six healthy young volunteers. The large circles represent points which differ statistically $(P<0.02)$ from the mean of the three base-line values. 
TABLE V

Effects of the Ingestion of One Egg White (6 $\mathrm{g}$ Protein) upon Plasma Glucagon, Insulin, and GLI in Four Human Volunteers

\begin{tabular}{|c|c|c|c|c|c|c|c|c|c|c|}
\hline $\operatorname{Min} . \ldots \ldots \ldots \ldots$ & $\ldots-20$ & -10 & 0 & 15 & 30 & 45 & 60 & 90 & 120 & 150 \\
\hline Glucose mean $(\mathrm{mg} / 100 \mathrm{ml})$ & 101 & 100 & 101 & 101 & 99 & 99 & 97 & 96 & 98 & 96 \\
\hline $\pm S E M$ & 2 & 2 & 3 & 3 & 4 & 3 & 4 & 3 & + & 3 \\
\hline Insulin mean $(U / m l)$ & 17 & 14 & 15 & 17 & 14 & 14 & 14 & 13 & 13 & 13 \\
\hline$\pm \mathrm{SEM}$ & 8 & 6 & 6 & 7 & 5 & 5 & 5 & 4 & 6 & 6 \\
\hline Glucagon mean $(p g / m l)$ & 94 & 99 & 91 & 96 & 95 & 106 & 99 & 94 & 104 & 97 \\
\hline$\pm \mathrm{SEM}$ & 18 & 19 & 17 & 19 & 15 & 16 & 17 & 16 & 17 & 14 \\
\hline GLI mean $(n g / m l)$ & 0.7 & 0.7 & 0.7 & 0.7 & 0.8 & 0.7 & 0.7 & 0.7 & 0.7 & 0.7 \\
\hline$\pm \mathrm{SEM}$ & 0.1 & 0.1 & 0.1 & 0.1 & 0.1 & 0.1 & 0.1 & 0.1 & 0.1 & 0.1 \\
\hline
\end{tabular}

the circulation. The mean maximal triglyceride rise was only $8 \mathrm{mg} / 100 \mathrm{mg}(\mathrm{SEM} \pm 5)$, and chylomicrons were not detectable by electrophoretic techniques. Yet, despite the absence of chylomicronemia, the responses of the hormones were unimpaired. Mean glucagon rose 73 $\mathrm{pg} / \mathrm{ml}(\mathrm{SEM} \pm 34)$, insulin $10 \mu \mathrm{U} / \mathrm{ml}$ (SEM \pm 8 ), and GLI $1.6 \mathrm{ng} / \mathrm{ml}(\mathrm{SEM} \pm 0.3)$. Mean maximal rises of these hormones were approximately as great or, in the case of insulin, greater than in the intact dogs. However, the rise in insulin coincided with an unexplained rise in glucose, which could well account for it. Mean maximal responses of the hormones in the three types of experiments, fat absorption with and without chylomicronemia and chylomicronemia without fat absorption,

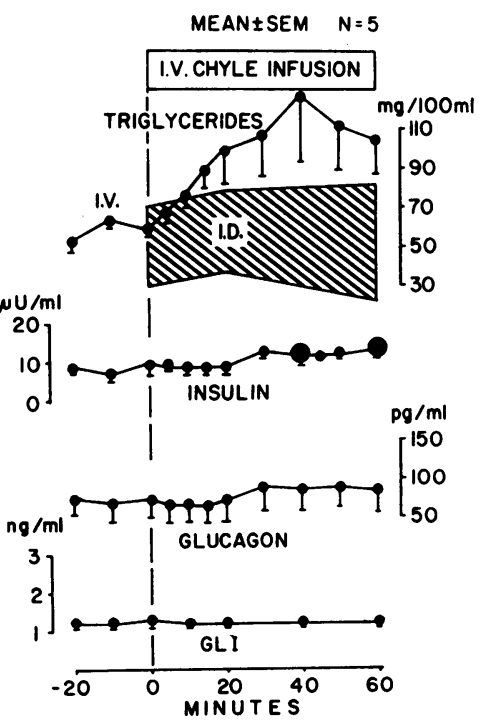

Figure 6 The effect of canine chyle, infused intravenously at a rate of $1.1-2.1 \mathrm{ml} / \mathrm{min}$ for $60 \mathrm{~min}$ upon glucagon, insulin, and GLI in a group of five conscious dogs. The large circles represent points which differ statistically $(P<0.02)$ from the mean of the three base-line values. are compared in Table VI. The results suggest that the response of glucagon and if it does, in fact, constitute a response, that of insulin to fat absorption is mediated by a signal from the gut rather than by chylomicronemia.

The effect of medium-chain triglycerides on glucagon and insulin. Only one hormone, pancreozymin-cholecystokinin, is known to be released during fat absorption (11) and to stimulate glucagon and insulin secretion (12). Despite this, there is, at present, no means of proving that pancreozymin alone is the enteric sig-

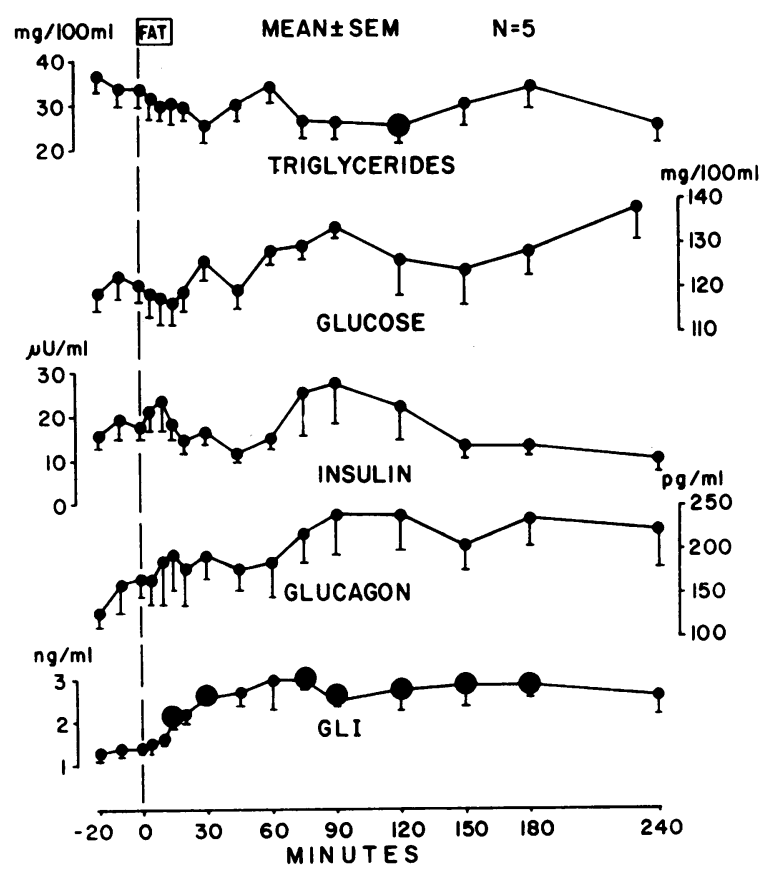

FIGURE 7 The effect of intraduodenal administration of 10 $\mathrm{g} / \mathrm{kg}$ of peanut oil in a group of five conscious dogs with a thoracic duct fistula. The large circles signify points which differ statistically $(P<0.02)$ from the mean of the three base-line values. 
TABLE VI

Fiffects of Intraduodenal Administration of Medium-Chain Triglycerides (11)g $\mathrm{kg}$ ) upon Plasma Insulin, Glucagon, and GLI in Nine Dogs

\begin{tabular}{|c|c|c|c|c|c|c|c|c|c|c|c|c|c|c|}
\hline $\operatorname{Min} \ldots \ldots \ldots$ & -20 & -10 & 0 & 5 & 10 & 15 & 20 & 30 & 45 & 60 & 90 & 120 & 150 & 180 \\
\hline Glucose mean $(\mathrm{mg} / 100 \mathrm{ml})$ & 87 & 89 & 90 & 88 & 85 & 84 & 85 & 85 & 85 & 86 & $81 *$ & $81 *$ & $82^{*}$ & $82^{*}$ \\
\hline \pm SEM & 2 & 2 & 3 & 3 & 3 & 3 & 4 & 4 & 4 & 4 & 5 & 4 & 3 & 3 \\
\hline Insulin mean $(\mu U / m l)$ & 11 & 11 & 9 & 9 & 11 & 12 & 11 & 11 & 10 & 11 & 10 & 8 & 9 & 10 \\
\hline$\pm \mathrm{SEM}$ & 2 & 2 & 1 & 1 & 2 & 2 & 2 & 2 & 1 & 2 & 2 & 1 & 1 & 1 \\
\hline Glucagon mean $(p g / m l)$ & 82 & 75 & 77 & 9.3 & 88 & 84 & 76 & 81 & 8.3 & $105^{*}$ & 95 & 94 & 89 & 93 \\
\hline$\pm \mathrm{SEM}$ & 2.3 & 22 & 20 & 30 & 25 & 19 & 14 & 14 & 14 & 22 & 17 & 14 & 14 & 15 \\
\hline GLI mean $(n g / m l)$ & 1.7 & 1.7 & 1.6 & 1.6 & 1.7 & 1.8 & $2.0 \pm$ & $2.3 \ddagger$ & $2.2 \ddagger$ & $2.4 \ddagger$ & $2.6 \ddagger$ & $2.5 \ddagger$ & $2.5 \ddagger$ & $2.5 \ddagger$ \\
\hline \pm SEM & 0.1 & 0.2 & 0.1 & 0.1 & 0.2 & 0.1 & 0.2 & 0.3 & 0.2 & 0.3 & 0.3 & 0.3 & 0.3 & 0.3 \\
\hline
\end{tabular}

$P$ was calculated by paired comparison against the mean of the base line.

$* P<0.05$.

$\ddagger P<0.01$.

nal that mediates the islet cell responses to fat absorption. It is, however, possible to design an experiment that might reveal the existence of a mediating signal other than pancreozymin. For example, preliminary studies of Go and Summerskill ${ }^{3}$ indicate that, in contrast to long-chain triglycerides, the absorption of medium-chain triglycerides is not accompanied by a release of pancreozymin-cholecystokinin. If glucagon and insulin were to rise during the absorption of medium-chain triglycerides, this would suggest that enteric signals other than pancreozymin may mediate the islet cell response to a fat meal.

$10 \mathrm{~g} / \mathrm{kg}$ of medium-chain triglycerides was, theretore, administered intraduodenally to a group of nine dogs, and glucagon, insulin, and GLI were measured.

${ }^{3}$ Personal communication.
As shown in Table VII, the glucagon response to intraduodenally administered medium-chain triglycerides was negligible, except for a small and statistically significant increase at $60 \mathrm{~min}(P<0.025)$. Insulin concentration did not change significantly. Plasma glucose decreased from $90 \mathrm{mg} 100 \mathrm{ml}(\mathrm{SEM} \pm 3)$ at zero time to $82 \mathrm{mg}$ $100 \mathrm{ml}(\mathrm{SEM} \pm 3)$ at $150 \mathrm{~min}$. The results do not reveal the existence of an enteric signal for glucagon secretion during the absorption of triglycerides that does not stimulate pancreozymin secretion.

Statistically significant increments in GLI were observed during the absorption of medium-chain triglycerides, but these were small compared with the rises in GLI induced by the absorption of long-chain triglycerides. These findings raise the possibility that the release of both the signal to the islets of Langerhans

TABLE VII

Relationships of Fat Absorption and of Chylomicronemia to Mean Maximal Increments $\pm S E M$ of Glucagon, Insulin, and GLI

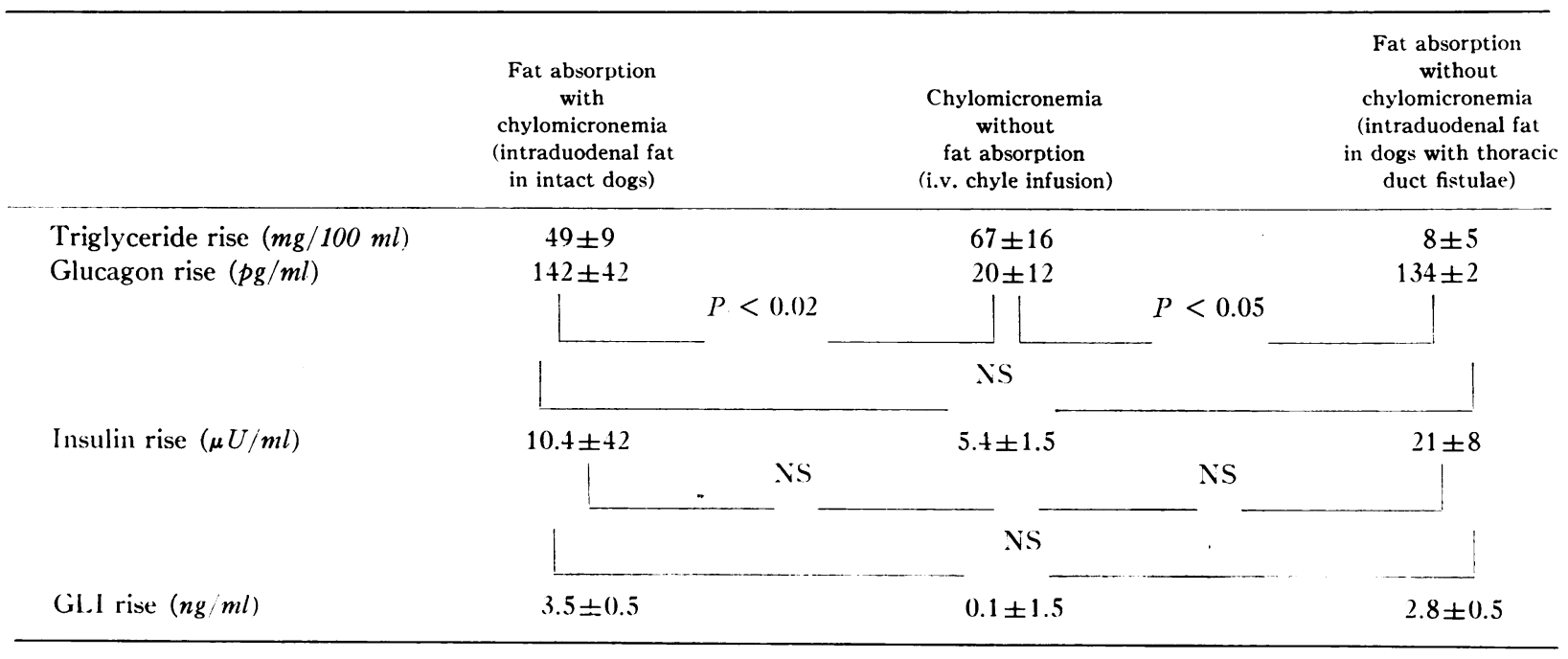


and of GLI is somehow linked to one or more of the several metabolic events peculiar to the absorption of long-chain triglycerides.

\section{DISCUSSION}

The foregoing studies reveal that in the dog the absorption of a fat meal is accompanied by increased secretion of glucagon and GLI and an extremely small rise in insulin. The latter agrees with earlier work in human subjects by Pi-Sunyer et al. (1) in which a very small increase in insulin was noted soon after the ingestion of a fat meal. In the present study mean insulin rose $5 \mu \mathrm{U} / \mathrm{ml}$ at $15 \mathrm{~min}$. Glucagon and GLI, not previously studied during fat absorption, increased far more strikingly; mean glucagon rose significantly at 15 min and remained significantly elevated throughout almost all of the 240 min experiment, reaching a level of $151 \mathrm{pg} / \mathrm{ml}$ at $45 \mathrm{~min}$. GLI increased $2.0 \mathrm{ng} / \mathrm{ml}$ at $45 \mathrm{~min}$ and remained above base line levels for approximately $3 \mathrm{~h}$. When the fat was presented in emulsified form, the response of glucagon and GLI were far more impressive and occurred with a fat load of only $1 \mathrm{~g} / \mathrm{kg}$, well within the physiologic range.

The studies strongly suggest that the response of glucagon to the absorption of fat is the consequence of a signal released from the gut itself, rather than of postprandial chylomicronemia. Chylomicronemia induced by the intravenous infusion of chyle obtained from the thoracic duct of other dogs fed peanut oil did not excite the changes in glucagon, insulin, or GLI observed during fat absorption. Moreover, the intraduodenal administration of the peanut oil elicited a rise in glucagon, insulin, and GLI in most of the dogs with a thoracic duct fistula despite exclusion of the absorbed fat from the circulation. These findings constitute powerful evidence that the response of the islet cell hormones, particularly that of glucagon, to the ingestion of fat is the consequence of a signal from the gastrointestinal tract.

Long-chain triglycerides must now be added to the list of substances that, when administered intraduodenally, elicit the release of GLI from the gut. The magnitude of the GLI response to emulsified long-chain triglycerides was remarkable-even greater than its response to glucose absorption (13). The significance and function of the fat-induced rise in GLI is obscure at the present time.

The identity of the enteric signal released by the absorption of fat was not established; however, the only known substance released during fat absorption (11) and known to stimulate glucagon and insulin secretion (12) is pancreozymin-cholecystokinin. The fact that medium-chain triglycerides, which do not stimulate pancreozymin release, do not elicit the same islet cell response as long-chain triglycerides is consonant with the possibility that pancreozymin-cholecystokinin is the afferent signal.

On the other hand, the rise in insulin during fat absorption was extremely small, while the response of dogs given exogenous pancreozymin in doses as low as 19 Crick-Harper-Raper units over $20 \mathrm{~min}$ is many times greater. ${ }^{4}$ Possibly at a lower dose the insulin response would have diminished to a greater degree than the glucagon response, but this remains to be tested. Otherwise, one is forced to consider the possibility that the stimulatory action of pancreozymin upon the beta cells but not the alpha cells is somehow blocked during chylomicronemia. The fact that the mean maximal insulin rise during fat absorption in dogs with a thoracic duct fistula was somewhat greater than in intact dogs could be cited to support this possibility. A negative feedback relationship between lipemia and insulin secretion serving a regulatory function in blood lipid homeostasis would be teleologically attractive.

The physiologic significance of the glucagon response to the absorption of fat is, of course, unknown. The well-documented ability of glucagon to lower plasma triglycerides (14-17), conceivably by inhibiting hepatic release of lipoproteins (18), raises the possibility of a control system in which fat absorption stimulates the release of glucagon, thus reducing the rate of endogenous lipoprotein release during fat absorption and limiting postprandial hyperlipemia. In this respect, it is noteworthy that a statistically significant fall in triglycerides was observed in the dogs with a thoracic duct fistula during fat-induced hyperglucagonemia, but unfortunately, no control observations are available. Eaton and Kipnis (19) have previously suggested that carbohydrate-induced hyperlipemia might be the consequence of glucagon suppression by an increased intake of carbohydrate; since pancreozymin-induced glucagon secretion is readily suppressed by glucose (20), their suggestion is compatible with this scheme.

Human subjects exhibited only modest changes in insulin, glucagon, and GLI, which, although qualitatively similar to those observed in dogs, were smaller and, in the case of insulin and glucagon, lacked statistical significance. The difference in the response of humans may be a consequence of the oral route of administration with gastric retention of the oil and need not necessarily represent a species difference. In most of the subjects, the unpalatable peanut oil drink caused mild nausea and an unpleasant sensation of gastric fullness, that persisted throughout the entire experimental period and may well have retarded the entry of fat into the small intestine.

\footnotetext{
- Unpublished observations.
} 


\section{ACKNOWLEDGMENTS}

The authors wish to express their appreciation to Miss Kay McCorkle, Mrs. Shirley Harvey, Miss Virginia Harris, Mrs. Margaret Bickham, and Miss Sheila Rathod for their technical assistance.

This work is supported by NIH Grant AM 02700-14; Hoechst Pharmaceutical Company, Somerville, N. J.; The Upjohn Company, Kalamazoo, Mich.; Pfizer Laboratories, New York; Bristol Myers Company, New York; Mead Johnson Research Center, Evansville, Ind.; Lilly Research Laboratories, Indianapolis, Ind.; Wm. S. Merrell and Company, Cincinnati, Ohio; Rabbit $30 \mathrm{~K}$ Fund, and Dallas Diabetes Association, Dallas, Tex.

\section{REFERENCES}

1. Pi-Sunyer, F. X., S. A. Hashim, and T. B. Van Itallie. 1969. Insulin and ketone responses to ingestion of medium and long-chain triglycerides in Man. Diabetes. $18: 96$.

2. Schalch, D. S., and D. M. Kipnis. 1965. Abnormalities in carbohydrate tolerance associated with elevated plasma nonesterified fatty acids. J. Clin. Invest. 44: 2010.

3. Crespin, S. R., W. B. Greenough, III, and D. Steinberg. 1969. Stimulation of insulin secretion by infusion of free fatty acids. J. Clin. Invest. 48: 1934.

4. Balasse, E., and H. A. Ooms. 1968. Effét d'une élevation aigue du taux des acides gras libres (NEFA) sur la tolerance glucidique et la réponse insulinique a l'hyperglycémie chez l'homme normal. Rev: Fr. Etud. Clin. Biol. 13: 62 .

5. Hoffman, W. S. 1937. A rapid photoelectric method for the determination of glucose in blood and urine. J. Biol. Chem. 120: 51 .

6. Eggstein, M., and F. H. Kreutz. 1966. Eine neue bestimming der neutralfette im blutserum und gewebe. Klin. Wochenschr. 44: 262.

7. Aguilar-Parada, E., A. M. Eisentraut, and R. H. Unger. 1969. Pancreatic glucagon secretion in normal and diabetic subjects. Am. J. Med. Sci. $257: 415$.

8. Yalow, R. S., and S. A. Berson. 1960. Immunoassay of endogenous plasma insulin in man. J. Clin. Invest. 39: 1157.

9. Herbert, V., K. Lau, C. W. Gottlieb, and S. J. Bleicher. 1965. Coated charcoal immunoassay of insulin. J. Clin. Endocrinol. Metab. 25: 1375.

10. Müller, W. A., G. R. Faloona, E. Aguilar-Parada, and R. H. Unger. 1970. Abnormal alpha-cell function in diabetes: response to carbohydrate and protein ingestion. N. Engl. J. Med. 283: 109.

11. Wang, C. C., and M. I. Grossman. 1951. Physiological determination of release of secretin and pancreozymin from intestine of dogs with transplanted pancreas. $\mathrm{Am}$. J. Physiol. $164: 527$.

12. Unger, R. H., H. Ketterer, J. Dupré, and A. M. Eisentraut. 1967. The effects of secretin, pancreozymin, and gastrin on insulin and glucagon secretion in anesthetized dogs. J. Clin. Invest. 46: 630.

13. Böttger, I., G. R. Faloona, and R. H. Unger. 1972. The effect of calcium and other salts upon the release of glucagon-like immunoreactivity from the gut. J. Clin. Invest. $51: 831$.

14. Albrink, M. J., J. R. Fitzgerald, and E. B. Man. 1957. Effect of glucagon on alimentary lipemia. Proc. Soc. Exp. Biol. Med. 95 : 778.

15. Paloyan, E., and P. V. Harper, Jr. 1961. Glucagon as a regulating factor of plasma lipids. Metab. (Clin. Exp.). 10: 315 .

16. Amatuzio, D. S., F. Grande, and S. Wada. 1962. Effect of glucagon and the serum lipids in essential hyperlipemia and in hypercholeșterolemia. Metab. (Clin. Exp.). $11: 1240$.

17. Heimberg, M., I. Weinstein, and M. Kobout. 1969. The effects of glucagon, dibutyryl cyclic adenosine $3^{\prime}, 5^{\prime}$ monophosphate, and concentration of free fatty acid on hepatic lipid metabolism. J. Biol. Chem. 244: 5131.

18. DeOya, M., W. F. Prigge, D. E. Swenson, and F. Grande. 1971. Role of glucagon on fatty liver production in birds. Am. J. Physiol. 221: 25.

19. Eaton, R. P., and D. M. Kipnis. 1969. Effect of glucose feeding on lipoprotein synthesis in the rat. Am. J. Physiol. 217 : 1153.

20. Ohneda, A., E. Parada, A. M. Eisentraut, and R. H. Unger. 1968. Characterization of response of circulating glucagon to intraduodenal and intravenous administration amino acids. J. Clin. Invest. 47: 2305. 